„Bohemistyka” 2020, nr 1, ISSN 1642-9893

Joanna CZAPLIŃSKA

Uniwersytet Opolski

Marcin FILIPOWICZ

Uniwersytet Hradec Králové

\section{W poszukiwaniu austronostalgii w czeskiej pamięci subiektywnej}

Keywords: Czech literature, memory studies, austronostalgy, family memory, Lubomír Martínek

Slowa kluczowe: literatura czeska, studia pamięci, austronostalgia, pamięć rodzinna Lubomír Martínek

\section{Abstract}

The paper's topic is presence or absence of austronostalgy in subjective sayings. Essays by the Czech author Lubomír Martínek and memories of representatives of 13 three-generations average Czech families are the source material. The authors' reflections concentrate on lack of austronostalgy in these subjective testimonies and the reason for this absence. One of them leads to Cathrin Horel theory that well-developed countries which did not owe their progress to the Habsburg monarchy forgot common past very quickly. The second one concerns Czech revival discourse in the 19th century with the main goal to became independent from Austro-Hungarian Empire.

Głównym tematem artykułu jest obecność lub brak austronostalgii w wypowiedziach subiektywnych. Materiałem źródłowym są eseje czeskiego autora Lubomíra Martínka oraz wspomnienia przedstawicieli 13 przeciętnych przypadkowych czeskich rodzin. Refleksje autora koncentrują się z jednej strony na braku austronostalgi w tych subiektywnych świadectwach, a $\mathrm{z}$ drugiej na przyczynach tej nieobecności Pierwsza z nich nawiązuje do teorii Cathrin Horel, że kraje dobrze rozwinięte, które nie zawdzięczają swojego postępu monarchii Habsburgów, bardzo szybko zapomniały o wspólnej przeszłości. Druga dotyczy czeskiego dyskursu odrodzeniowego w XIX wieku, którego głównym celem było uniezależnienie się od imperium austrowęgierskiego.

\section{Nienostalgiczna niepamięć}

System budowanej przez cały wiek XIX habsburskiej tożsamości państwowej, jak też związanych z nią referencji kulturowych i polityki pamięci ${ }^{1}$, zostały w państwach powstałych po rozpadzie AustroWęgier w dużej mierze zniszczone. Nie wszędzie jednak proces programowego zapominania, pozostający $\mathrm{w}$ symbiozie $\mathrm{z}$ budowaniem nowych tożsamości państwowych (Connerton 2014, s. 348-349), przebiegał z taką samą intensywnością. Nie istnieje bowiem żadna korelacja między długościa panowania Habsburgów a pamięcią o nich w dzisiejszych społeczeństwach. Jak twierdzi francuska badaczka Catherine Horel, nostalgiczna pamięć o Felix Austria związana jest bezpośrednio z charakterem politycznych losów danego regionu. Im bardziej bowiem dramatyczna była późniejsza historia i im większe było zapóźnienie cywilizacyjne, tym silniejsze było w danym miejscu poczucie austronostalgii. Czasy panowania Franciszka Józefa zostały na takich obszarach zapamiętane jako okres wspaniałego współistnienia, spokoju i rozwoju. Natomiast w krajach, gdzie monarchia nie pełniła misji cywilizacyjnej, pamięć o niej była raczej negatywna i szybciej zanikała (Horel 2012, s. 7). Ziemie czeskie bez wątpienia należały do tej drugiej grupy. W I Republice Czechosłowackiej przystąpiono do intensywnego zapominania, które objęło obszary przestrzeni publicznej oraz oficjalnego dyskursu kulturowego. Tendencja ta została dodatkowo wzmocniona po II wojnie światowej przez reżim komunistyczny, jak też ogólną rewizję stosunku do wszystkiego, co niemieckie (Zimmermann 2009, s. 321-348). Nawet po 1989 roku, kiedy zaczęło się przywracanie pamięci całego regionu Europy Środkowej, w Czechach nie można było zaobserwować szczególnie intensywnych prób nostalgicznego rewidowania dziedzictwa multietnicznego cesarstwa (Horel 2012, s. 16-19). Znamiennym tego przykładem jest chociażby tekst preambuły Konstytucji Republiki Czeskiej, który odwołuje się do dobrych tradycji dawnej państwowości ziem Korony Czeskiej

${ }^{1}$ Por. np. J. Křen 1990, s. 34; Schorske 2000, s. 25-27; Bělohradský 1991, s. 41; Štaif 2005, s. 117-118; Kořalka 1996, s. 20; Bruckmüller, 1984, s. 91-97. 
i państwowości czechosłowackiej ${ }^{2}$, pomijając kompletnie okres habsburski, tak jakby państwowość czeska w tym okresie nie istniała, a Habsburgowie nie pozostawili po sobie żadnych dobrych modernizacyjnych tradycji, tylko ,jarzmo zniewolenia”.

Zanim podejmiemy nasze rozważania na temat potencjalnego kształtu czeskiej pamięci o Austrii, przypomnijmy pokrótce definicję pojęcia nostalgii. Marek Zaleski pisze na przykład, że nostalgia umieszcza ideał w przeszłości i jest to jedyna rzecz pewna, jaką można o niej powiedzieć (Zaleski 1996, s. 11). W rozwinięciu próby zdefiniowania tego pojęcia badacz dostrzega wiele możliwych biegunów, na których uczucie to się plasuje - od cierpienia poprzez zadowolenie aż po ukojenie pamięcią pozbawioną bólu, ale też stwierdza, iż nostalgiczność to rodzaj oglądu świata:

Mówiąc o nostalgii, mówimy o stosunku do przeszłości i do zanurzonych w niej przedmiotów (Zaleski 1996, s. 12).

Nostalgia jest tęsknotą za tym, co było i zniknęło, zanikło, ale a priori - w przekazie narratora - było lepsze niż rzeczywistość doświadczana obecnie. Trochę inne aspekty zjawiska nostalgii uwypukla Svetlana Boym, która pisze, że nostalgia charakteryzuje sie patosem wywołanym przez uczucie, że przeszłość jest nieodwołalna i jest czymś zanurzonym w bezczasie, niezmiennym i zastygłym w wiecznej doskonałości. Nostalgia zdaniem badaczki jest również doświadczeniem dostarczajacym rozkoszy, ponieważ przeszłość jest czymś, co nas już bezpośrednio nie dotyczy i nie stanowi żadnego wyzwania. Im bardziej dane wydarzenie jest oddalone w czasie, tym większa jest rozkosz wspominania. Nawet to, co było źródłem bólu, nie wraca już jako ból. Nostalgia karmi się bowiem pamięcią, z której wszelki ból został usunięty (Boym 1990, s. 328-341).

W naszym przekonaniu oficjalny czeski dyskurs kulturowy pozbawiony jest śladów pamięci o monarchii habsburskiej, wpisującej się

\footnotetext{
${ }^{2}$ Ústava České republiky, ze dne 16. prosince 1992, ústavní zákon č. 1/1993 Sb. ve znění ústavního zákona č. 347/1997 Sb., 300/2000 Sb., 448/2001 Sb., 395/2001 Sb., 515/2002 Sb., 319/2009 Sb., 71/2012 Sb. a 98/2013 Sb.
}

W tak pojmowaną nostalgię. W literaturze czeskiej trudno jest odnaleźć paralelę do słów Aloisa Woldana, który, wymieniwszy nazwiska szeregu polskich pisarzy tworzących mit Austrii, zauważa:

Szczególne zainteresowanie wzbudza najmłodsza generacja »galicyjskich« autorów, jak Włodzimierz Paźniewski (ur. 1942) i Ryszard Sadaj (ur. 1950), którzy, być może pod wpływem funkcjonującego już mitu Austrii, podchwycili go w swoich tekstach (Woldan 2018)

A należy mieć w pamięci, że teksty kultury kształtują świadomość również poprzez dostarczanie bodźców stymulujących przywoływanie pewnych wspomnień. Ich brak może powodować, że również pamięć w danym obszarze zostaje wycofana (Hansen 2015, s. 198). Jednakże poza oficjalną pamięcią historiograficzną czy ujawniającą się w tekstach kultury, pojawia się cała sfera pamięci subiektywnej, lokalnej, nieciągłej lub nieprawomocnej, która pozostaje często w rozbieżności z oficjalnymi dyskursami i formalnymi systematyzacjami (Foucault 1998, s. 19-23). W takich pokładach pamięci centralna i funkcjonalnie systematyzująca perspektywa nie istnieje. Ich istotą jest bowiem wielość perspektyw, podkreślających wyjątkowość i indywidualność podmiotów oraz analizy świata ich doświadczeń. Ten rodzaj pamięci często w dość istotny sposób uzupełnia historyczną faktografię i oficjalny dyskurs kulturowy o sferę subiektywnych przeżyć i opinii. Może zatem w tej sferze przechowały się jakieś formy nostalgicznego myślenia o cesarstwie? Dlatego też za przedmiot naszych rozważań obraliśmy wypowiedzi subiektywnej sfery eseistyki i pamięci rodzinnej. Naszym celem było sprawdzenie, czy również tutaj widoczny jest brak austronostalgii. Jako materiał źródłowy posłużyły nam osobiste refleksje zawarte w esejach czeskiego pisarza i publicysty, Lubomíra Martínka oraz wywiady z przedstawicielami 13 trzypokoleniowych czeskich rodzin przeprowadzone w ramach projektu Agencji Grantowej Republiki Czeskiej Rodinná pamět' a mezigenerační proměna identit realizowanego przez Wydział Filozoficzny Uniwersytetu Palackiego w Ołomuńcu (Švaříčková Slabáková, Sobotková, Filipowicz... 2018, s. 11-20). 


\section{Eseistyka Lubomíra Martínka}

Lubomír Martínek (ur. 1954), pisarz i eseista, który w roku 1979 wyemigrował do Francji, jest specyficznym przykładem pisarza emigracyjnego. Wyjazd traktował on bowiem jako drugie narodziny, okazję do rozwinięcia skrzydeł, a przede wszystkim do nieograniczonej możliwości podróżowania po świecie. W jego twórczości trudno się dopatrzeć śladów wykorzenienia, tak typowych dla wielu emigrantów, odwrotnie - dewizą życiową pisarza wydaje się być navigare necesse est, vivere non est necesse. Podróże i brak więzi z ojczyzną odcisnęły piętno także na utworach prozatorskich Martínka, których budowę można określić jako kłącze, bez wyraźnego początku i końca. Jego eseje, które już jako gatunek nacechowany jest dygresyjnością i nielinearnością, również wpisują się w rizomatyczne upodobania autora stanowiąc silva rerum, zbiór refleksji na różnorodne tematy, nad którymi Martínek się pochylił podczas swoich podróży.

Zarówno fakt emigracji, jak i poznawania innych kultur w charakterze bynajmniej nie pobieżnego turysty, ale osoby pragnącej przeniknąć mentalność, historię i styl życia odwiedzanych nacji, pozwoliły na uzyskanie znacznego dystansu wobec własnego narodu, co w zbiorze esejów o wymownym tytule Nomad's Land zostało skwitowane słowami:

Město, v němž jsem se narodil, se jmenuje České Budějovice. Národnost obsažená v místě narození. Nesnesitelné. [..] Vrchol je, že mě se jménem, které musím vláčet ve všech papírech, legitimacích, průkazech, smířil až úrúedník. Úředník, který mi na jakési povolení napsal: Cuzco Budezowice, což jsem přetvořil na Cuzco Budweiser. [...] Zároveň jsem tak setřel místo, proti němuž sice nic nemám, ale jež zní jako povolení k pobytu (Martínek 1994, s. 5).

Dla naszych rozważań jest to spojrzenie wielce cenne, gdyż oznacza perspektywę osoby, która mikroskop służący do obserwacji swoich rodaków zamieniła na teleskop pozwalający na ogarnięcie wzrokiem całych zjawisk społecznych, w tym również stosunku Czechów do austrowęgierskiej przeszłości. A historia niewątpliwie należy do jednego z tematów, nad którym eseista się pochyla:
Stejně jako není úniku před rozlohou, polohou a podnebím místa, kde se člověk narodil, není úniku ani před historií. Můžeme ji studovat, popírat, přehlížet, vysmívat se jí, ale pořád jsme ji poznamenáni při nejmenším v bezděčně převzatých stereotypech a zvyklostech, tak jak se v průběhu staletí ustálily. Protivná nepominutelnost historie může vést až k posedlosti dějinami a $\mathrm{k}$ jejich přeceňování. Dějiny stojí za pozornost pouze do té míry, do jaké umožňují udělat si představu, čím jsme více či méně ovlivněni. Tato nebezpečná hračka se může proměnit $\mathrm{v}$ impuls, potupu, mávátko, záminku k explozi šílenství či v erupci energie. Přikládat ji větší důležitost než si zasluhuje, vede k posedlosti, která si v ničem nezadá s posedlostí ideologickou. Ostatně i zapomínání patř̌i neoddělitelně k životu, bez něj by se proměnil v peklo podobné naprosté amnézii (Martínek 2000, s. 165-166).

Jaka jest zatem opinia Martínka na temat występowania, bądź nie, nostalgii za monarchią habsburską? Czeski autor nie pozostawia złudzeń, Wiedeń został wpisany w świadomość Czechów tak samo silnie jak Praga:

Ocitl jsem se znovu ve Vídni. Tentokrát ve společnosti mladé ženy, která sice prožila v Praze osmnáct let, ale znala porze její fasády. Díky této podivuhodné okolnosti jsem sloužil veVídni jako průvodce Prahou [...]. Rozdíly se stíraly podobnostmi, které jsem poprvé v životě byl přinucen formulovat a pojmenovat. Omítky, kabáty, půllitry, popelníky, cedulky s nabubřelými tituly na dveřích... Především ale způsob chůze, držení př́borů, stisk ruky. [...] Rozdíl byl pouze v tom, že ve Vídni byly budovy vynášející byrokraty ještě na bubřenějsí, ještě bombastičtější (Martínek 1994, s. 8-9).

\section{W innym fragmencie zaś czytamy:}

Po třech letech honu [...] jsem se vrátil. Opět do místa, kde jsem nikdy nebyl. Do Vídně. Kdyby to nebylo bývalo napsané na ceduli, myslel bych, že jsem v Praze. [...] Nezbylo mi nic jiného než uznat, že střední Evropa skutečně existuje (Martínek 1994, s. 6-7).

Dla Martínka Praga i Wiedeń są bliźniaczymi miastami, wyrosłymi ze wspólnej historii ostatnich kilku stuleci i podobnej mentalności. Czy jednak można to uczucie nazwać nostalgią? W pierwszym z przytoczonych fragmentów na plan pierwszy wysuwa się przerośnięta biurokracja - niewątpliwa spuścizna C. K. monarchii, dostrzegalna również we współczesnych Czechach i na Słowacji, aczkolwiek postrzegana zdecydowanie nie jako przedmiot tęsknoty ze względu na swa doskonałość. Myślenie o Pradze i Wiedniu jako miastach o podobnej 
tożsamości również raczej prowadzi do konkluzji, że to nie monarchia, ale raczej Europa Środkowa, na dodatek w skali mikro, istnieje w świadomości czeskiego pisarza jako pewna wspólnota, widziana przez wspomniany teleskop. Z punktu widzenia obieżyświata, jakim jest Martínek, w takim obrazie Europy Środkowej akcentowane są kolejne negatywne cechy, wskazujące na dominantę, której autor nie wyraził wprost, lecz która czytelna jest między wierszami: drobnomieszczaństwo. Trudno więc w tego typu wspomnieniu Austro-Węgier dostrzec szersze pojmowanie monarchii jako zjawiska wielokulturowego, wielonarodowego, w pewnym momencie dziejowym walczącego na różne sposoby o własną autonomię. Perspektywa, z której pisze Martínek, zamyka się w wąskiej zależności Pragi od Wiednia.

Dostrzegalna tożsamość obu miast czytelna jest także w innym aspekcie. Na niemal wszystkie kontynenty, via obóz dla uchodźców w Treiskirschen, emigrowało po 1968 roku tysiące Czechów. Nie może być przypadkiem, iż wielu z nich decydowało się jednak na pozostanie właśnie w tym miejscu, w Austrii. Martínek interpretuje to zjawisko jako nie emigrację, ale przeprowadzkę:

Nevyhnul jsem se ani setkání s pražskými práteli a známými. Lidmi, kteří se vypařili, jak se sluší a patří, ale dali přednost podobnosti před rozdílností. Lidmi, kteří se rozhodli raději přestěhovat než odejít (Martínek 1994, s. 9).

Wyjechać, a jednak czuć się ,,jak u siebie”, to z jednej strony scheda po Austro-Węgrach, gdy podróżowanie w ramach monarchii nie było wyzwaniem ekstremalnego przekraczania granic. Z drugiej jednak strony jest to przejaw zachowawczości i potrzeby utrzymania swoistego status quo, gdyż w nowym miejscu wszystko - prócz języ$\mathrm{ka}$ - jest niezmiernie podobne do miejsca, które się opuściło. Jeśli by więc rozważać nostalgię za Austro-Wegrami w tym kontekście, będzie ona nie tyle wspomnieniem, co gwarantem pewnej stabilizacji, czy może raczej - brakiem wywrócenia dotychczasowego świata „do góry nogami”, co niewątpliwie dotknęło emigrantów obierających azymut na inne kraje czy wręcz kontynenty. Lecz ponownie, jeśli by się nad tym zjawiskiem zastanowić, czy można mówić o nostalgii, czy raczej o więzi, uwarunkowanej historycznie i kulturowo - ponownie pomiędzy niewielkim wycinkiem Austro-Węgier a Czechami?

\section{Pamięć rodzinna}

Przyjrzyjmy się teraz pamięci rodzinnej. Może w tej sferze zachowały sie jakieś ślady nostalgicznego wspominania ,starych dobrych austriackich czasów", przekazywane z pokolenia na pokolenie? Ten rodzaj pamięci stał się w ostatnich latach przedmiotem zwiększonego zainteresowania badaczy, co jest prawdopodobnie związane z odkryciem przez współczesne studia pamięci opublikowanego w I połowie XX wieku dzieła Maurice'a Halbwachsa Społeczne ramy pamięci. Francuski socjolog pisze $\mathrm{w}$ nim, że na pamięć indywidualną mają wpływ ramy społeczne, a jedną z nich tworzy właśnie rodzina (Erll 2011, s. 305). Również Paul Ricoeur zauważa, że płaszczyzna relacji $\mathrm{z}$ bliskimi (rodziną) jest jednym $\mathrm{z}$ trzech przedmiotów atrybucji pamięci. Tworzą one całkowicie jej odrębny i szczególny rodzaj, tak zwaną pamięć leżącą między biegunami spójności stanów świadomości ja indywidualnego (pamięć indywidualna), a bytami zachowującymi i przywołującymi wspólne wspomnienia (pamięć zbiorowa), do których indywidualne ja przynależy (Ricoeur 2006, s. 163 i 173). Pamięć rodzinna jest w świetle tych ustaleń niezmiernie ważnym składnikiem pamięci indywidualnej i zbiorowej. Wspomnienia rodzinne tworzą jednocześnie modele, przykłady, wiedzę, za pomocą których wyraża się ogólne działanie grupy, oraz są nieustannie przetwarzane w taki sposób, aby nadawać rodzinie sens i być w zgodzie z jej przekonaniami. Jest to zatem istotny element budujący tożsamość indywidualną i zbiorową oraz stanowiący pewnego rodzaju miejsce przejściowe między dyskursem kulturowym, a pamięcią indywidualną.

Pojawia się jednak pytanie, czy w ogóle zasadne jest poszukiwanie w pamięci rodzinnej współczesnych Czechów śladów austrowęgierskiej nostalgii. Czy nie jesteśmy już zbyt oddaleni w czasie, żeby móc na nie natrafić? Pozytywnej odpowiedzi wydaje się dostarczać tom International Yearbook of Oral History and Life Stories z roku 1993 pod 
redakcją socjologa Daniela Bartaux i historyka Paula Thompsona, którzy zaproponowali podjęcie namysłu nad treściami przekazywanymi przez rodziców swoim dzieciom. Teksty zawarte w tym tomie pokazały, że są to przede wszystkim trwałe rodzinne modele i mity. Bez względu na to, czy dotyczyło to angielskich rodzin, które przeżyły Holocaust, czy pokoleniowych ról kobiet w jednym włókniarskim mieście w Kolumbii, czy też pamięci rodzinnej byłych niewolników w Brazylii, chociaż niewolnictwo w Brazylii zostało zniesione w 1888 roku, we wszystkich przypadkach redaktorzy znajdowali dowody transmisji wzorców międzypokoleniowych. Zauważano też, że owe wzory mogą sięgać aż do piątego czy nawet szóstego pokolenia wstecz (Švaříčková Slabáková, Sobotková, Filipowicz 2000, s. 15). Zasadnymi wydają się zatem pytania, czy w czeskiej pamięci rodzinnej pojawiają się jakiekolwiek elementy austrowęgierskiej nostalgii, czy współbrzmią one z dyskursem kulturowym i w końcu, czy są transmitowane na kolejne pokolenia, ewentualnie do jakich przekształceń w trakcie takiej międzypokoleniowej transmisji dochodzi.

W celu przeprowadzenia badania skorzystaliśmy z korpusu pogłębionych wywiadów przeprowadzonych metodą oral history z 13 czeskimi rodzinami w ramach wspominanego już wcześniej projektu Rodinná pamět' a mezigenerační promény identity. Zebrane one zostały w okresie od czerwca 2015 do lipca 2016 roku (Švařríčková Slabáková, Sobotková, Filipowicz... 2018, s. 53). Badane rodziny reprezentowały wszystkie warstwy społeczne, a jedynym warunkiem uczestnictwa w projekcie było, że wywiadów udzielić muszą przedstawiciele trzech pokoleń tej samej rodziny. Najstarsi uczestnicy projektu byli urodzeni w połowie lat dwudziestych XX wieku, najmłodsi z kolei w połowie lat dziewięćdziesiątych tegoż stulecia. Poszukiwanie śladów austronostalgii w przedmiotowym korpusie wywiadów jest o tyle uzasadnione, że członkom rodzin zadawano też pytania o tzw. wielką historię, czyli zachęcano ich, by interpretowali dzieje swojej rodziny na tle wydarzeń dotyczących większych zbiorowości narodowych lub państwowych. Innymi słowy, jeżeli sami bez żadnej zachęty nie wspomnieli niczego na temat stosunku ich rodziny do mo- narchii habsburskiej, to mogli mieć ku temu jeszcze sposobność w tej części rozmowy, która dotyczyła wydarzeń historycznych.

Przede wszystkim należy stwierdzić, że w pamięci zdecydowanej większości rodzin nie zachowały się żadne ślady austronostalgii albo przynajmniej nie zostały one wyartykułowane. 10 z 13 rodzin, z którymi przeprowadzano wywiady, w żaden sposób nie przedstawiało historii swojej rodziny w kontekście austrowęgierskim. Z jednej strony można to oczywiście zrzucić na karb zbyt dużej odległości czasowej i bardziej angażujących emocjonalnie wydarzeń XX wieku (powstanie I Republiki, II wojna światowa, komunizm, praska wiosna, normalizacja czy nawet aksamitna rewolucja). Z drugiej strony jednak owe dramatyczne wydarzenia powinny być może wywoływać uczucie takiej nostalgii jako chęci powrotu do czasu spokoju i bezpieczeństwa. Innym wytłumaczeniem może być też koncentrowanie się narracji na prywatnej sferze życia rodzinnego. Być może jednak jest też tak, że intensywnie odczuwana austronostalgia nie istnieje także w tej sferze czeskiej pamięci. Należy podkreślić, że istnienie związków rodziny z Austrią, czy jakiekolwiek odwołania kulturowe do funkcjonowania w ramach austro-węgierskiego państwa, zachowało się przede wszystkim w pamięci najstarszego pokolenia i tylko w jednej rodzinie (A) pamięć ta została przekazana dalej, choć oczywiście w zmodyfikowanej formie.

Jak to interpretować? Czy zatem pamięć doświadczenia życia w monarchii habsburskiej była w każdym kolejnym pokoleniu redukowana, nie będąc przy tym specjalnie atrakcyjną emocjonalnie? Najmłodsze pokolenie zupełnie już się do niego nie odnosi, nawet w przypadku tej rodziny, gdzie pamięć związków z Austrią została przekazana. Wspomnienie zostało mocno zredukowane i oparte na niepewności epistemologicznej:

Ano, vzpomínala, jak se její tatínek narodil ve Vídni... Nejsem si jistá, jestli ve Vídni, ale myslím, že jo (A3).

Zacytowane zdanie stanowi uwagę odnoszaca się do centralnego w opowiadaniu narratorki A1 (babci narratorki A3) wydarzenia z ro- 
dzinnej historii, czyli faktu, że jej ojciec urodził się w Wiedniu. Innymi słowy można stwierdzić, że pamięć monarchii w tym pokoleniu już nie istnieje i raczej nie można mówić, że ulega ono przekazywanemu oddolnie w rodzinach wpływowi austronostalgii.

Jaki jest zatem kształt pamięci o Austrii w tych nielicznych wspomnieniach przedstawicieli najstarszego pokolenia badanych rodzin? Pierwszą zauważalną kwestia jest ekonomiczny aspekt funkcjonowania rodziny w monarchii. Są to jednak opowieści, które nie zdradzają śladów nostalgii. Mają one charakter rzeczowych konstatacji, że do Wiednia jeździło się na służbę albo na handel, albo jeszcze w inny sposób zarabiać pieniądze:

[...] tatínek byl pánský krejčí. A když neměl práci, tak, jak to bývalo za c. k. Rakouska, tak šel do Vídně. No a tam si vydělal nějaký peníze (A1).

Tenkrát to byla móda za c. k. Rakouska, že když děvčata dodělaly školu, tak šly do práce do Vídně (A1).

[...] on kdysi jak bylo ještě za Rakousko-Uherska, on jezdil jako do tých Rakous a vždycky jako vozil něco, to se jako potem prodávalo jako po té dědině a to (E1).

Opowiadania te nie zawierają jednak żadnych elementów żalu czy też tęsknoty za tym, że po powstaniu Czechosłowacji relacje ekonomiczne zostały przerwane. Co ciekawe, ekonomicznej prosperity monarchii nie zestawia się także z bezprawiem i zgrzebnością czasów wczesnego komunizmu. Austria oddala się zatem, ale bez poczucia żalu, po prostu staje się częścią zachodniego i oddzielonego żelazną kurtyna świata, z którym płaszczyzna wspólnego doświadczenia jest bardzo ograniczona. Nie jest to jednak dla narratorów powód do narzekania, że kiedyś za Austrii było lepiej i że należy żałować, iż tamten świat większych ekonomicznych możliwości odszedł w przeszłość. Widać to wyraźnie w opowieści narratorki A2, która w 1968 roku odwiedziła w Wiedniu swoja cioteczna babkę, mieszkająca tam jeszcze od czasów monarchii. W opowieści narratorki nie znajdziemy niczego na temat wspomnień wspólnego współistnienia w jednym państwie, ale zachwyt nad niedostępnym w Czechosłowacji światem zachodniego konsumeryzmu oraz trochę gorzkie uwagi na temat skąpstwa wiedeńskiej „ciotki”:

No a my jsme tam potom byli s Rudou, s manželem, ve Vídni v šedesátém osmém. To nám bylo jednadvacet, to bylo tenkrát možné jako vyjet, tak že jsme tam byli se podívat. A tenkrát jsme neměli peníze, nebo něco takovýho, teta nám dala 500 šilinků a řekla „tak, a už vás nebudu živit”, takže to mně připadalo takový divný (A2).

Tylko w jednym przypadku rodzinna pamięć zachowała wspomnienie, w którym Wiedniowi przypisywany jest wysoki potencjał kulturowy, coś na kształt wzorca godnego naśladowania, starych dobrych czasów, które charakteryzowały się wysokim poziomem wysublimowania. Narratorka A1 wspomina, że jej dziadek, który przez jakiś czas mieszkał w Wiedniu i pracował tam jako krawiec, wrócił wprawdzie do Ołomuńca, ale przywiózł z sobą dobre wiedeńskie obyczaje i był z tego dumny:

Tatínkův tatínek, čili můjdědeček, hrozně rád jezdil do Olomouce. Naši bydleli na Nových Sadech. On byl takový společenský, od té Vídně, jak se můj tatínek narodil ve Vídni. Tak vždycky odpoledne si vypil kávu a šel do parku, do Smetanových sadů (A1).

Trudno jest jednak powiedzieć, żeby to wspomnienie dziadka, starającego się również w czechosłowackim już Ołomuńcu żyć według wiedeńskich standardów, zawierało w sobie szczególnie silny ładunek nostalgii. Nie jest bowiem uzupełnione o porównawczy komentarz, że dzisiaj takiej kultury już nie ma, albo ogólnym narzekaniem na upadek dobrych obyczajów.

W dwóch wywiadach pojawia się natomiast tendencja do odwoływania się do starych austriackich czasów w postaci utartych fraz, które niekoniecznie muszą oznaczać prawdziwą nostalgiczną tęsknote za Austrią i jej porzadkami. Jest to raczej rodzaj schematów semantycznych mających wyrazić niezadowolenie $\mathrm{z}$ aktualnego stanu rzeczy lub też zdziwienie aktualnymi porządkami. Narratorka H1 wspomina, jak kiedyś dostała „pětku” z matematyki. Bojąc się swojego surowego ojca, uciekła do domu dziadków w tej samej wsi. Dziadek, który był w jej opowieści uosobieniem dobra i humoru, starał się ją 
przed znacznie bardziej surowym ojcem ochronić. Kiedy już ojciec po narratorkę przyszedł, dziadek stwierdził, że po pierwsze wszystko umie, bo ją przepytał, a po drugie: ,za císaře pána byla pětka nejlepší ocenění" (H1). Omawiane zjawisko jest jeszcze bardziej widoczne w opowieści narratorki I1. Wspomina ona swoich rodziców, którzy jej zdaniem byli demokratami i w pełni akceptowali powstanie Czechosłowacji. Niemniej jednak odwoływanie się do Austrii w codziennych rozmowach stanowiło rodzaj skonwencjonalizowanej frazy, będącej wyrazem dezaprobaty dla ich zdaniem niezbyt udanych form organizacji życia społecznego i politycznego. Wynikało to nie tyle z nostalgii za Austrią, lecz z idealizowaniem czasu własnej młodości, jak też z tęsknoty za bezpieczeństwem i ładem:

Na Rakousko vzpomínali rádi, protože to považovali, samozřejmě s ohledem na své mládí, za idylickou dobu. V̌̌ecko klapalo, jak mělo, a platil tam taková zásada policajt byl na svém místě, úředník byl ctěná osobnost, farář dělal to, co měl, že jo, starosta se staral, sedlák hospodařil (I1).

Kiedy zatem życie w I Republice, czy też później w socjalistycznej Czechosłowacji, płatało im figle, przywoływali pamięć Austrii:

[...] oni měli takowej výraz - nešel proud např́iklad (to nešel často, jo) nebo vlak měl zpoždění anebo nejel vůbec - a měli krásnej výrok, kterej, kterej. . to vystihoval, a sice „tohle by se za Rakouska nestalo" (I1).

Warto jednak zauważyć, że narratorka przywołuje to wspomnienie w odniesieniu do drobnych spraw życia codziennego, natomiast nie odnosi go do znacznie trudniejszych politycznych doświadczeń Czechów w poprzednim stuleciu.

\section{Czemu Czesi (nie?) tęsknią za cesarstwem?}

Można zatem postawić kilka hipotez dotyczących przyczyn znacznie ograniczonej obecności Austro-Węgier w czeskim dyskursie kulturowym i pamięci subiektywnej. Pierwsza, która się nasuwa, ma podłoże historyczne - wielowiekowe uzależnienie Czechów od monarchii habsburskiej w sposób naturalny zrodziło niechęć do Wiednia.
Powtórzenie truizmu, iż czeskie odrodzenie narodowe dążyło do wyemancypowania się od niemieckiej dominacji można wzmocnić, posługując się słowami Jiřego Holego:

Jednou z tezí českého politického nacionalismu 19. století bylo, že národní jazyk a kultura mohou být zachovány jen za předpokladu vlastního státu. Stát měl tudíž v první řadě chránit životní zájmy národa a zabezpečit jeho kontinuální existenci jakožto zvláštní kulturní entity (Holý 2010, s. 59).

Powstanie państwa czeskiego (a w rezultacie działań politycznych czechosłowackiego) w roku 1918 było urzeczywistnieniem idei głoszonych przez zarówno czeskich, jak i słowackich „,budzicieli”. Od roku 1918 zaczęto pisać nową historię - historię, która miała nawiązywać do tradycji sprzed habsburskiej dominacji (uwzględniającą również tradycję konfesyjną) i budować staro-nową tożsamość opartą o zredukowane, acz ciagle żywotne ideały słowiańskiej wzajemności. Austro-Węgry zostały więc wyparte z pamięci w sensie psychologicznym jako twór niechciany, wywołujący traumatyczne wspomnienia. Rok 1918 był okazją do ostatecznego spuszczenia kurtyny.

Kolejnym z powodów braku tęsknoty Czechów za c. k. Austrią można uznać brak tęsknoty za symbolem władcy - Czechosłowacja po 1948 roku miała ich bowiem w nadmiarze - nie tylko w postaci I sekretarza Komunistycznej Partii Czechosłowacji, premiera, ale i prezydenta Republiki, jak bowiem zauważa Holý, „Politický systém Československa komunistické éry měl také specifické rysy v tom, že zachoval úřad prezydenta republiky" (Holý 2010, s. 9). Ale też wcześniejsze sentymenty Czechów lokowane były inaczej - to nie Franz Josef, ale Tomáš Garrique Masaryk był przedmiotem kultu i nostalgicznych wspomnień:

Pro lid byl otcem, který dal svým dětem, národu, největší dar, jaký si lze představit - svobodu (Holý 2010, s. 63)

- pisze dalej Holý. Demokratyczne poglądy Masaryka stały też na przeciwległym biegunie niż kojarzony z Habsburgami autorytaryzm czy komunistyczny totalitaryzm. Przewrotne uzasadnienie lekceważącego stosunku wobec c. k. władców oferuje zaś Lubomír Martínek, 
który jego powody widzi właśnie w przytaczanych rodzinnych wspomnieniach:

Tam, kde má venkovan př́iležitost nahlédnout do ložnice panovníka, protože jeho sestřenice čirou náhodou myje nádobí ve vládcově kuchyni, se těžko může zrodit bezbřehý obdiv k pomazaným hlavám (Martínek 2000, s. 161).

Tezy stawiane przez Holego i Horel korespondują ze sobą, gdyż badacze ci spoglądają na Czechy i Czechów przez teleskop. Holý swoje refleksje na temat Czechów pisał jako emigrant, Horel zaś jest przedstawicielką francuskich historyków zajmujących się dziejami Europy Środkowej. Ich poglądy łączą punkty widzenia wynikające zarówno z nacechowanego subiektywnie spojrzenia Holego, który na swoich rodaków patrzy przez pryzmat własnych doświadczeń, jak i obiektywnego, neutralnego emocjonalnie spojrzenia Horel. W zestawieniu z nienaukowymi, spontanicznymi wypowiedziami zarówno Martínka, jak i reprezentantami rodzin o pamięci sięgającej czasów monarchii dyskurs ten zlewa się w jedno. Horel ponadto przywołuje koncepcję A. D. Smitha o etnikum poziomym i pionowym:

[...] „veritkální ethnie" nezahrnují aristokracii a jsou za to sice demokratičtější, ale i radikálnější ve svém zacházení s národem. [...] Češi jsou velmi dobře charakterizování jako „vertikální ethnie” tím, že bez aristokracie a demokraticky uvedli v platnost svá historická práva a po roce 1918 zaujímali vědomě protihabsburský postoj (Horel 2012, s. 10).

Idąc tymi tropami można domniemywać, iż braku austronostalgii wśród Czechów można upatrywać na kilku płaszczyznach: postępie cywilizacyjnym, który na ziemiach czeskich nie ustępował europejskiemu, ba, w drugiej połowie XIX wieku go wręcz wyprzedzał i nie zawdzięczał go tylko bytności w monarchii; dyskursowi narodowościowemu Czechów zarówno w wieku XIX, jak i po roku 1918; bliskości (nie tylko geograficznej, ale przede wszystkim mentalnej) Pragi do Wiednia, niwelującej kulturotwórcze mechanizmy, które można zaobserwować w wielu krajach stanowiących w przeszłości integralne cześci monarchii habsburskiej, a które w XX wieku znalazły się na cywilizacyjnych peryferiach Europy.

\section{Literatura}

B ěl o h radský V., 1991, Mitteleuropa: rakouská říše jako metafora, [w:] idem, Přirozený svět jako politický problém (Eseje o človéku pozdní doby), Praha, s. XXX-XXX.

B o y m S., 1990, Dyskomfort nostalgii, [w:] Konteksty pamięci, Češi a Němci 1780-1918, Praha, s. 328-341.

B r u c k m ü 11 e r E., 1984, Nation Österreich Sozialhistorische Aspekte ihrer Entwicklung, Wien-Graz-Köln.

C onnert on P., 2014, Siedem rodzajów zapomnienia, przeł. LIDEX, [w:] Konteksty pamięci, red. K. Kończal, Warszawa, s. 348-349.

E 11 A., 2011, Locating Family in Cultural Memory Studies, ,Journal of Comparative Family Studies" 42, nr 3, s. XXX-XXX;

F o u c a u 1 t M., 1998, Trzeba bronić społeczeństwa, przeł. M. Kowalska, Warszawa.

$\mathrm{H}$ a $\mathrm{n}$ s e $\mathrm{n}$ J., 2015, Theories of Memory and the Imaginative Force of Fiction, [in:] The Ashgate Research Companion to Memory Studies, red. S. Kattago, London-New York, s. XXX-XXX.

H o lý J., 2010, Malý český člověk a skvělý český národ. Národní identita a postkomunistická transformace společnosti, przeł. Z. Uherek, Praha.

H o r e 1 C., 2012, Habsburská monarchie: transnacionální misto paměti, „Časopis Matice moravské", 131, suppl. 3, s. 7.

K oř a 1 k a J., 1996, Češi v Habsburské ríši a v Evropě 1815-1914, Praha

Kř e n J., 1990, Konfliktní společenství: Češi a Němci 1780-1918, Praha.

Martín e k L., 1994, Nomad's Land, Praha.

M a r tín e k L., 2000, Mimochodem, Praha-Litomyšl.

R i c œ u r P., 2006, Pamięć, historia, zapomnienie, przeł. Janusz Margański, Kraków.

S c h o r s k e C. E., 2000, Vídeň na přelomu století, przeł. J. Svoboda, Brno.

Š ta i f J., 2005, Obezřetná elita. Česká společnost mezi tradicí a revoluci 1830-1851 , Praha.

Švaříčková Slabáková R., Sobotková I., Filipowicz M., Zac hová A., Kohoutová J., P etrů M., 2018, I Rodina může mít svou pamět', Praha, s. 11-20.

W old a n A., 2018, Mit Austrii w literaturze polskiej, [w:] Interakcje. Leksykon porozumiewania polsko-niemieckiego. Online: http://www. polska-niemcy-interakcje. pl/articles/show/26 [dostep 6. 10. 2018].

$\mathrm{Z}$ a le s k i M., 1996, Formy pamieci, Warszawa.

Z i m m e r m a n n V., 2009, Kultúrnopolitické vztahy medzi NDR a Československém $v$ 50. a 60. rokoch 20. storočia, [in:] Kultura jako nositel a oponent politických zámérů. Německo-české a německo-slovenské kulturni styky od poloviny 19. století, red. D. Kováč, M. Marek, J. Pešek, R. Prahl, Ústí nad Labem, s. $321-348$. 